\title{
ŠIUOLAIKINIŲ TECHNOLOGIJŲ NAUDOJIMO TRUKMĖS POVEIKIS PAAUGLIŲ LAIKYSENAI IR LIEMENS RAUME- NU STATINEI IŠTVERMEI
}

\section{Anelė Gedmantaitė, Vilma Dudonienė}

Lietuvos sporto universitetas

\section{SANTRAUKA}

Tyrimo pagrindimas. Sparčiai tobulëjančios ir lengvai prieinamos šiuolaikinès technologijos užima vis didesnę vaikų ir paauglių kasdienio gyvenimo dalị (Paavonen et al., 2010). Išmanieji telefonai, planšetès ir kompiuteriai (tiek nešiojami, tiek stacionarūs) tapo neatsiejama jaunų žmonių mokymosi ir laisvalaikio dalimi (Young et al., 2012; Korpinen et al., 2013). Taip pat padaugejjo vaikų ir paauglių laikysenos sutrikimų, dažnas skundžiasi įvairaus pobūdžio skausmu nugaroje, ypač kaklinèje ir juosmenineje dalyse (Brink et al., 2013; Bimboga, Korhan, 2014).

Tikslas - nustatyti šiuolaikinių technologijų naudojimo trukmès ir paauglių laikysenos bei statinès raumenų ištvermès sąsajas.

Metodai. Buvo tiriami 84 asmenys (60 merginos, 24 vaikinai). Tiriamųjų laikysena įvertinta 1987 m. W. W. K. Hoeger (Arcinavičius ir kt., 2004) vizualia laikysenos vertinimo anketa, technologijų dažnio, trukmès, pojūčių nugaroje ir fizinio aktyvumo klausimyno anketa, statinė raumenų ištvermé - McGill (2002) metodika.

Rezultatai. $90 \%$ tiriamuju pasireiškè nemalonūs pojūčiai nugaroje (13\% visoje nugaroje, $9 \%$ kakle, $35 \%$ viršutinèje nugaros dalyje, $43 \%$ juosmeninèje nugaros dalyje). Visi tiriamieji naudojosi šiuolaikiniais technologijų įrenginiais (75\% kompiuteriu, 10\% planšete, 95\% telefonu). $10 \%$ tiriamųjų laikysena puiki ( $45-50$ balų), 35\% - gera (44-45 balai), 55\% - laikysena patenkinama (39-30). Nesinaudojančių kompiuteriu laikysenos vidurkis siekè 40,2 balo, o tų, kurie praleido 4 ir daugiau valandų -43 , nesinaudojančių planšete -40 , o tų, kurie naudojosi planšete $1-2 \mathrm{~h}-39$. Tiriamieji, kurie nesinaudoja telefonu daugiau nei skambinant, surinko 42 balus, o tie, kurie naudojosi 4 ir daugiau valandų - 38,7 balo. Vertinant moksleivių laikyseną ir statinę liemens raumenų ištvermę nustatyta teigiama vidutinio stiprumo reikšminga koreliacija tarp laikysenos ir nugaros bei dešinès pusès raumenų statinès liemens ištvermès $(r=0,33 ; r=0,41)$, praleisto laiko prie kompiuterio ir statinès liemens raumenų ištvermès - silpni ir vidutinio stiprumo teigiami koreliaciniai ryšiai, reikšmingas ryšys buvo su kairès pusès statine liemens raumenų ištverme $(r=0,24)$. Vertinant laiką, praleistą naudojantis planšete, ir statinę liemens raumenų ištvermę, gauti neigiami silpni koreliaciniai ryšiai, reikšmingas ryšys - su pilvo raumenų statine ištverme $(\mathrm{r}=-0,29)$. İvertinus telefono naudojimo trukmę, laikyseną ir ištvermę, nustatyti neigiami silpni ir vidutinio stiprumo reikšmingi koreliaciniai ryšiai.

Išvados. $10 \%$ tiriamujų nustatyta puiki laikysena, 35\% - gera, 55\% - patenkinama. Nustatytas tiesioginis vidutinio stiprumo reikšmingas ryšys tarp paauglių laikysenos ir liemens raumenų statinès ištvermès. Šiuolaikinių technologijų priemonėmis kasdien naudojasi $100 \%$ tiriamųjų, o vidutinė naudojimosi trukmė yra keturios valandos. Gauti reikšmingi silpni ir vidutinio stiprumo ryšiai tarp šiuolaikinių technologijų naudojimo trukmès ir statinès liemens raumenų ištvermès bei laikysenos.

Raktažodžiai: šiuolaikinès technologijos, paauglių laikysena, statinè raumenų ištvermè.

Copyright (C) 2020 Anelè Gedmantaitè, Vilma Dudonienė. Published by Lithuanian Sports University.

This is an Open Access article distributed under the terms of the Creative Commons Attribution 4.0 International License, which permits unrestricted use, distribution, and reproduction in any medium, provided the original author and source are credited. 
Šiuolaikinių technologijų naudojimo trukmės poveikis paauglių laikysenai ir liemens raumenų statinei ištvermei

\section{IVADAS}

Vaikų ir paauglių laikysena - jų sveikatos pamatas. Netaisyklinga laikysena kelia susirūpinimą visame pasaulyje. Dažni mokyklinio amžiaus vaikų nusiskundimai skausmu, diskomfortu ir nuovargiu, jaučiamu nugaroje, skatina išsiaiškinti šių simptomų priežastis. Šiais naujų technologijų laikais vis populiarèja tokie komunikaciniai ir informaciniai įrenginiai kaip kompiuteris, nešiojamasis kompiuteris, planšete, išmanieji telefonai ir pan. (Straker et al., 2011). Jų dèmesį ir laisvalaikio užimtumą dažnai lemia šios modernios technologijos. Nuo pat 2000 metų žaibiškas kompiuterių atsiradimas rinkoje lėmè vis augantị vaikų ir paauglių, turinčių šias technologijas namuose, skaičių (Hakala et al., 2006). Visgi kartu su šiuolaikinėmis technologijomis vaikai ir paaugliai dažnai ėmė skųstis kaklo, pečių lanko, viršutinès ir apatinès nugaros dalies skausmais. Vis dažniau pastebima ir netaisyklinga laikysena, sumažejusi statinė liemens raumenų ištvermè. Manoma, kad tai tiesiogiai susiję su technologijų naudojimo trukme ir informacijos apie taisyklingą, ergonomišką šių naujų įrenginių naudojimą trūkumu (Gustafsson et al., 2011; Gold et al., 2012).

Tyrimo tikslas - nustatyti šiuolaikinių technologijų naudojimo trukmès ir paauglių laikysenos bei statinès raumenų ištvermès sąsajas.

\section{METODAI}

Tiriamieji. Buvo tiriami 84 asmenys (60 merginų, amžiaus vidurkis $15,4 \pm$ 0,6 m.; 24 vaikinai, amžiaus vidurkis $15,5 \pm 0,8$ m.). Dalyvavimas tyrime savanoriškas. İtraukimo ị tyrimą kriterijai: fiziškai sveiki 14-18 metu amžiaus moksleiviai, tėvų / globejjų sutikimas dalyvauti tyrime, ūminių ir / ar lètinių ligų neturèjimas. Neįtraukimo ị tyrimą kriterijai: ūmūs ar lètiniai susirgimai (traumos, širdies ir kraujagyslių sistemos ligos, endokrininès sistemos ligos ir kt., galinčios daryti įtaką tyrimo duomenims), neturintys tèvų / globejų sutikimo.

Tyrimo organizavimas ir eiga. Tyrimas pradètas gavus Lietuvos sporto universiteto Bioetikos komisijos leidimą atlikti biomedicinini tyrimą, mokyklos, kurioje buvo atliekamas tyrimas, ir tėvų sutikimus. Tyrimas truko nuo $2017 \mathrm{~m}$. sausio 9 d. iki vasario 28 d. Tiriamieji ir jų tèvai buvo supažindinti su tyrimo aktualumu, jo eiga. Kiekvienam moksleiviui skirtas individualus laikas mokyklos medicinos seselès kabinete, netrikdant jo mokymosi proceso. Vizito metu pateikta užpildyti anketa, ịvertinanti laikyseną ir statinę raumenų ištvermę. Užtikrintas anonimiškumas ir konfidencialumas. 


\section{Tyrimo metodai}

Anketine apklausa. Anketa sudaryta iš 14 klausimų. Ja siekta išsiaiškinti ilgalaikio šiuolaikinių technologijų naudojimo dažnį, kiekị, tiriamojo fizinį aktyvumą, bei, jo nuomone, esamą nugaros sveikatos būklę. Taip pat pažymimi tam tikri tiriamojo ypatumai, galintys turèti įtakos jo laikysenai (dominuojanti ranka, regos aštrumas ir pan.). Tiriamųų buvo prašoma užpildyti anketą ir apibraukti atitinkamus variantus.

Laikysenos vertinimas. Vertinant paauglių laikyseną naudota $1987 \mathrm{~m}$. W. W. K. Hoeger (Arcinavičius ir kt., 2004) vizuali laikysenos vertinimo sagitalioje ir frontalioje plokštumose anketa. Laikysena vertinama balais apžiūrint kiekvieną kūno segmentą sagitalioje ir frontalioje plokštumose. Jie vertinami tokiais kriterijais: 5 balai - puikiai, be nukrypimų; 3 balai - patenkinamai, matomas nedidelis ar vidutinis nukrypimas; 1 balas - blogai, matomi ryškūs nukrypimai. Susumavus kiekvienos kūno dalies įvertinimą, gaunamas balas, kuris nusako bendrą situaciją. Laikysena gali būti puiki, gera, patenkinama, bloga ir labai bloga (žr. lent.). Apžiūrint laikyseną iš nugaros, vertinama galvos padètis, pečių lanko simetrija, menčių padéčių kampai ir simetrija, juosmeniniai trikampiai, klubų simetrija, kelių ir čiurnų padètys. Vertinant laikyseną iš šono, atkreipiamas dėmesys ị stuburo fiziologinius linkius, pilvo padètí, dubens ir nugaros pasvirimą, kojų padètis.

Statines raumenu ištvermès vertinimas. Buvo naudoti izometrinès raumenų ištvermès testai. Juos sudare nugaros tiesiamųų raumenų ištvermès testas, pilvo raumenų ištvermès testas, dešinès ir kairès pusių šoninių liemens raumenų ištvermès testai pagal McGill (2002) metodiką. Rodikliai fiksuojami chronometru minutemis ir sekundèmis.

Norma laikoma, jei pilvą ir nugarą tiriamasis taisyklingai išlaiko mažiausiai 20-30 sekundžių, o kairę ir dešinę puses 10-20 sekundžių. Atlikus visus keturis testus, įvertinamas santykis tarp pilvo ir nugaros bei kairès ir dešinès pusių. Jei matomas didelis skirtumas, fiksuojamas kaip raumenų disbalansas.

Matematinė statistika. Tyrimo duomenys apibendrinti ir apdoroti Microsoft Office Exel 2013 kompiuterine ir SPSS matematine statistine programa. Duomenys pateikti procentais ir sekundèmis. Skirtumas tarp gautų duomenų yra laikomas statistiškai reikšmingu, kai $\mathrm{p}<0,05$. Ryšys tarp tiriamų rodiklių buvo apskaičiuotas naudojant Spearman'o koreliacijos koeficientą (r). Koreliacija yra silpna, kai $0<$ $\mathrm{r} \leq 0,3$, vidutinio stiprumo koreliacija $-0,3<\mathrm{r} \leq 0,8$ ir stipri koreliacija $-0,8<\mathrm{r} \leq 1$.

\section{TYRIMO REZULTATAI}

Anketinės apklausos duomenų analizė. Vertinant nemalonius jutimus nugaroje paaiškejjo, kad net $90 \%$ tiriamụju jie pasireiškia. Nuovargi jautė $24 \%$, skausmą 
Šiuolaikinių technologijų naudojimo trukmės poveikis paauglių laikysenai ir liemens raumenų statinei ištvermei

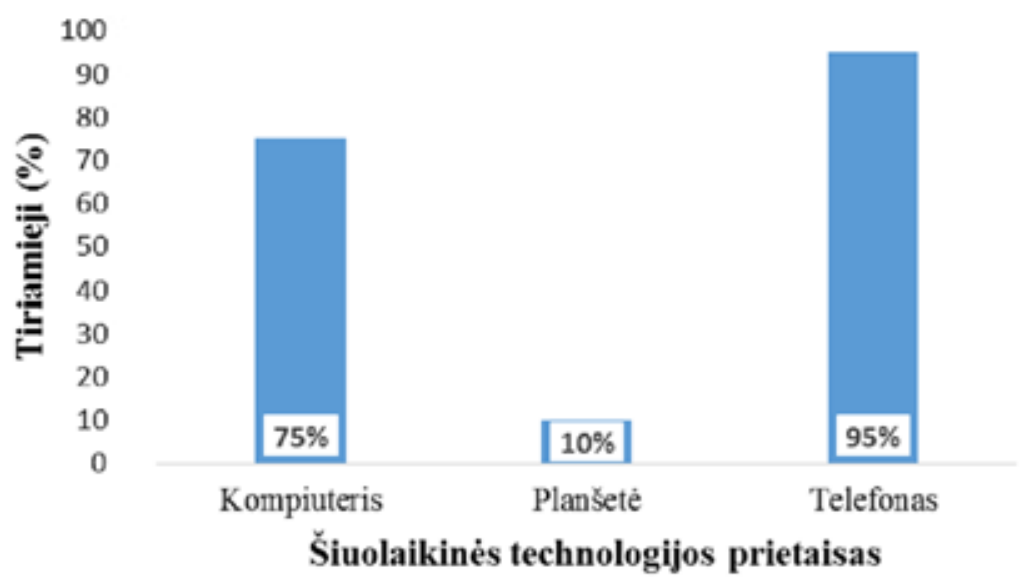

1 pav. Naudojimasis šiuolaikinėmis technologijomis

$27 \%$, diskomfortą $49 \%$ paauglių. Iš jų $13 \%$ tiriamujų nemalonūs jutimai pasireiškè visoje nugaroje, $9 \%$ kakle, $35 \%$ viršutineje nugaros dalyje, $43 \%$ juosmeninèje nugaros dalyje.

Visi tiriamieji naudojosi bent vienu šiuolaikinių technologiju įrenginiu. Nustatyta, kad 75\% tiriamujų naudojasi kompiuteriu, 10\% - planšete, $95 \%$ - telefonu (1 pav.).

Siekiant išsiaiškinti praleisto laiko prie kompiuterio trukmę per dieną paaiškèjo, kad prie kompiuterio didžioji dalis paaugliu (35\%) praleidžia iki $1 \mathrm{~h}$ per dieną, $20 \%-1-2 \mathrm{~h}, 15 \%-2-3 \mathrm{~h}, 5 \%-4$ ir daugiau valandų, $25 \%$ paauglių išvis nesinaudoja kompiuteriu. Vertinant laiką, praleistą naudojantis planšete per dieną, didžioji dalis tiriamujų apskritai nesinaudoja planšete $(80 \%), 10 \%$ paauglių nesinaudoja ja kiekvieną dieną, 5\% naudojosi iki $1 \mathrm{~h}$, kiti 5\% -1-2 h. Mobiliuoju telefonu ne skambinimo tikslais naudojasi didžioji dalis moksleivių 4 ir daugiau valandų per dieną (45\%), 20\% naudojasi 2-3 h, 15\% - 1-2 h ir 15\% iki $1 \mathrm{~h}, 5 \%$ telefonu nesinaudoja kitais tikslais.

Laikysenos vertinimo duomenų analizè. İvertinus moksleivių laikyseną pagal 1987 m. W. W. K. Hoeger (Arcinavičius ir kt., 2004) vizualią laikysenos vertinimo balais anketą, duomenys rodo, kad 10\% tiriamujų laikysena puiki (45-50 balų), 35\% - gera (44-45 balai), 55\% - patenkinama (39-30 balų). Niekam nenustatyta bloga ar labai bloga laikysena.

Tiriamujų laikysenos vidurkiai palyginti su įrenginių naudojimo trukme. Tų, kurie nesinaudojo kompiuteriu, laikysenos vidurkis siekè 40,2 balo, kurie naudojosi iki $1 \mathrm{~h}-39$ balai. Paauglių, kurie naudojosi kompiuteriu 1-2 h, balų vidurkis buvo 40,3, o tų, kurie praleido 4 ir daugiau valandų, laikysena siekè 43 balų vidurkị. 
Moksleivių, kurie nesinaudoja planšete, laikysenos balų vidurkis siekè 40 balų, kurie kasdien nesinaudoja -42 balus, tu, kurie naudojasi ja iki $1 \mathrm{~h}-37$ balus, kurie naudojasi planšete $1-2 \mathrm{~h}-39$ balus. Tiriamujų, kurie nesinaudoja telefonu kitais nei skambinimo tikslais, laikysenos balų vidurkis sieke 42 balus, kurie naudojasi iki $1 \mathrm{~h}-40,3$ balo, kurie naudojasi $1-2 \mathrm{~h}-40,3$, kurie naudojasi telefonu $2-3 \mathrm{~h}-$ 42 balus, o tų, kurie naudojasi 4 ir daugiau valandų, laikysenos balų vidurkis siekè 38,7 balo.

Liemens raumenų statinès ištvermès vertinimo duomenų analizė. İvertinus statinę raumenų ištvermę nustatyta, kad paauglių nugaros tiesiamụjų raumenų statinès ištvermès vidurkis yra $95 \mathrm{~s}$, pilvo raumenų $-87 \mathrm{~s}$, dešinès pusès liemens raumenų - $56 \mathrm{~s}$, kairès $-55 \mathrm{~s}$.

Palyginome tų, kurie naudojasi kompiuteriu, statinę raumenų ištvermę su naudojimo trukme. Gauti duomenys rodo, kad tų, kurie nesinaudoja kompiuteriu, nugaros tiesiamujų raumenų ištvermès vidurkis yra $86 \mathrm{~s}$, pilvo raumenų $-87 \mathrm{~s}$, dešinès pusès šoninių liemens raumenų - $64 \mathrm{~s}$, kairès - $54 \mathrm{~s}$. Moksleivių, kurie naudojasi kompiuteriu iki $1 \mathrm{~h}$ per dieną, nugaros tiesiamųų raumenų statinès ištvermès vidurkis yra $88 \mathrm{~s}$, pilvo raumenų - $77 \mathrm{~s}$, dešinès pusès šoninių liemens raumenų $-43 \mathrm{~s}$, kairès $-47 \mathrm{~s}$. Tų, kurie naudojasi kompiuteriu $1-2 \mathrm{~h}$ per dieną, nugaros tiesiamujjų raumenų statinės ištvermès vidurkis yra $104 \mathrm{~s}$, pilvo raumenų $94 \mathrm{~s}$, dešinès pusės šoninių liemens raumenų - $64 \mathrm{~s}$, kairès $-63 \mathrm{~s}$. Tų moksleivių, kurie naudojasi kompiuteriu 2-3 h per dieną, nugaros tiesiamujų raumenų statinès ištvermès vidurkis yra $90 \mathrm{~s}$, pilvo raumenų - $97 \mathrm{~s}$, dešinès pusès šoninių liemens raumenų $-60 \mathrm{~s}$, kairès $-57 \mathrm{~s}$. Tiriamujų, kurie naudojasi kompiuteriu 4 ir daugiau valandų per dieną, nugaros tiesiamujų raumenų statinès ištvermès vidurkis yra $120 \mathrm{~s}$, pilvo raumenų $-120 \mathrm{~s}$, dešinès pusès šoninių liemens raumenų $-69 \mathrm{~s}$, kairès $-67 \mathrm{~s}$ ( 2 pav.).

Ivertinus paauglių, kurie naudojasi planšetiniu kompiuteriu, statinę raumenų ištvermę su naudojimo trukme, duomenys rodo, kad tų, kurie nesinaudoja planšete, nugaros tiesiamujų raumenų ištvermès vidurkis yra $98 \mathrm{~s}$, pilvo raumenų $-96 \mathrm{~s}$, dešinès pusès šoninių liemens raumenų - $58 \mathrm{~s}$, kairès $-58 \mathrm{~s}$. Moksleivių, kurie kasdien nesinaudoja planšetiniu kompiuteriu, nugaros tiesiamųų raumenų statinės ištvermès vidurkis lygus $108 \mathrm{~s}$, pilvo raumenų - $48 \mathrm{~s}$, dešinès pusės šoninių liemens raumenu $-38 \mathrm{~s}$, kairès $-29 \mathrm{~s}$. Tų, kurie naudojasi iki $1 \mathrm{~h}$ per dieną, nugaros tiesiamujjų raumenų statinès ištvermès vidurkis yra $78 \mathrm{~s}$, pilvo raumenų $-45 \mathrm{~s}$, dešinès pusès šoninių liemens raumenu $-57 \mathrm{~s}$, kairès $-48 \mathrm{~s}$. Tie moksleiviai, kurie naudojasi planšetiniu kompiuteriu $1-2 \mathrm{~h}$ per dieną, nugaros tiesiamujų raumenų statinès ištvermès vidurkis yra $90 \mathrm{~s}$, pilvo raumenu - $84 \mathrm{~s}$, dešinès pusės šoninių liemens raumenu $-65 \mathrm{~s}$, kairès taip pat $65 \mathrm{~s}(3$ pav.) 
Šiuolaikinių technologijų naudojimo trukmės poveikis paauglių laikysenai ir liemens raumenų statinei ištvermei

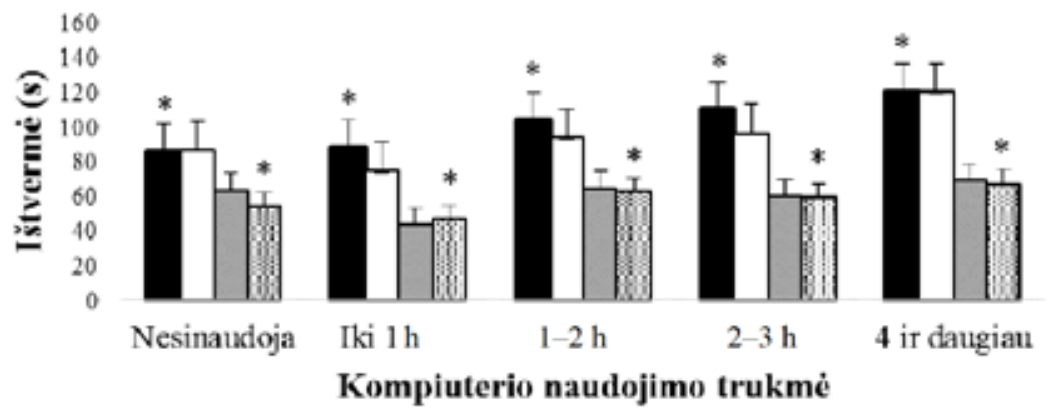

aNugaros tiesiamujų raumenụ statinés ištvermés vidurkis

口Pilvo raumenụ statinés ištvermés vidurkis

口Desinès pusès liemens raumenụ statinés ištvermés vidurkis

$\square$ Kairès pusés liemens raumenų statinés ištvermés vidurkis

Pastaba. ${ }^{*}-p<0,05$, koreliacija statistiškai reikšminga.

2 pav. Statinè raumenų ištvermè ir kompiuterio naudojimo trukmė

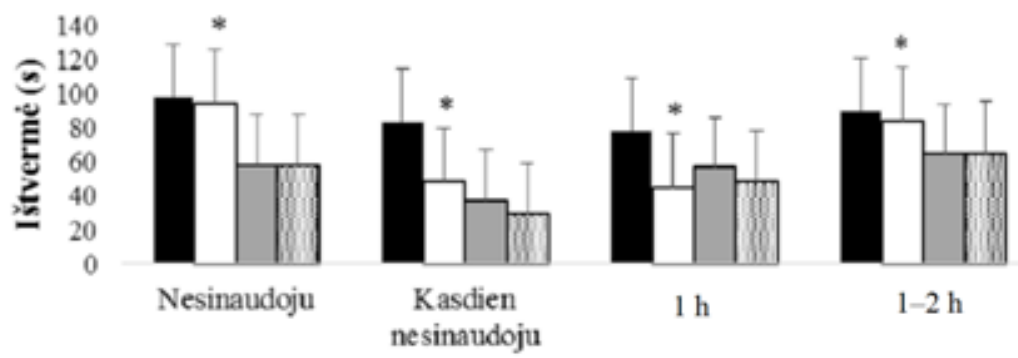

Planšetinio kompiuterio naudojimo trukmė per dieną

- Nugaros tiesiamujų raumenų statinés ištvermés vidurkis

口Pilvo raumenų statinés ištvermés vidurkis

口Dešinès pusés liemens raumenų statinès ištvermès vidurkis

口Kairés pusès liemens raumenų statinès ištvermés vidurkis

Pastaba. ${ }^{*}-p<0,05$, koreliacija statistiškai reikšminga.

3 pav. Statinė raumenų ištvermė ir planšetinio kompiuterio naudojimo trukmė 
İvertinus paauglių, kurie naudojasi kompiuteriu, statinę raumenų ištvermę su naudojimo trukme, gauti duomenys rodo, kad tų, kurie nesinaudoja telefonu ne skambinimo tikslais, nugaros tiesiamujų raumenų ištvermès vidurkis yra $90 \mathrm{~s}$, pilvo raumenų - $120 \mathrm{~s}$, dešinès pusès šoninių liemens raumenų $-83 \mathrm{~s}$, kairès $-58 \mathrm{~s}$. Tiriamujų, kurie naudojasi telefonu iki $1 \mathrm{~h}$ per dieną, nugaros tiesiamujų raumenų statinès ištvermès vidurkis yra $110 \mathrm{~s}$, pilvo raumenų - $101 \mathrm{~s}$, dešinès pusès šoninių liemens raumenų $-65 \mathrm{~s}$, kairès $-70 \mathrm{~s}$. Tų, kurie naudojasi telefonu 1-2 h per dieną, nugaros tiesiamujų raumenų statinès ištvermès vidurkis yra $106 \mathrm{~s}$, pilvo raumenų - $95 \mathrm{~s}$, dešinès pusės šoninių liemens raumenų $-53 \mathrm{~s}$, kairès $-54 \mathrm{~s}$. Tų moksleivių, kurie naudojasi telefonu 2-3 h per dieną, nugaros tiesiamujų raumenų statinès ištvermès vidurkis yra $109 \mathrm{~s}$, pilvo raumenu - 85 min, dešinès pusès šoninių liemens raumenų $-70 \mathrm{~s}$, kairès $-54 \mathrm{~s}$. Tiriamujų, kurie naudojosi telefonu 4 ir daugiau valandų per dieną, nugaros tiesiamųų raumenų statinės ištvermès vidurkis yra $82 \mathrm{~s}$, pilvo raumenų $-79 \mathrm{~s}$, dešinès pusès šoninių liemens raumenų $-50 \mathrm{~s}$, kairès taip pat $50 \mathrm{~s} \mathrm{(4} \mathrm{pav.)}$

Paauglių šiuolaikinių technologijų naudojimo trukmès, laikysenos ir liemens raumenų statinès ištvermès vertinimo sąsajų analizè. İvertinus ir apibendrinus paauglių šiuolaikinių technologijų naudojimo trukmès, laikysenos ir liemens raumenų statinès ištvermès vertinimo duomenis, nustatyti silpni ir vidutinio stiprumo tiek teigiami, tiek neigiami koreliaciniai ryšiai (žr. lent.). Vertinant moksleivių laikyseną ir statinę liemens raumenų ištvermę nustatyta teigiama vidu-

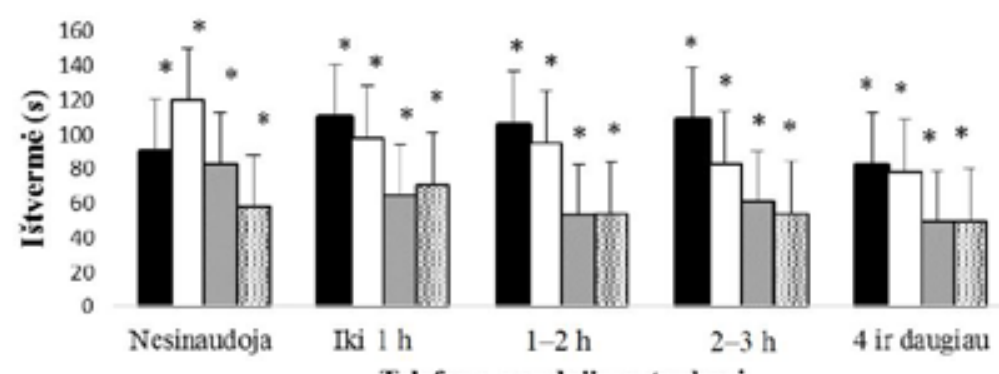

Telefono naudojimo trukmè

- Nugaros tiesiamujų raumenų statinés ištvermés vidurkis

QPilvo raumenų statinès istvemèes vidurkis

口Desinés pusés liemens raumeny statinés ištvemés vidurkis

aKairés pusès liemens raumenų statinés ištvermés vidurkis

Pastaba. ${ }^{*}-\mathrm{p}<0,05$, koreliacija statistiškai reikšminga.

4 pav. Statinė raumenų ištvermė ir telefono naudojimo trukmė 
Šiuolaikinių technologijų naudojimo trukmės poveikis paauglių laikysenai ir liemens raumenų statinei ištvermei

tinio stiprumo reikšminga koreliacija tarp laikysenos ir nugaros bei dešinės pusès statinès liemens raumenų ištvermès $(r=0,33 ; r=0,41)$. Tarp laikysenos ir pilvo bei kairès pusès liemens raumenų statinès ištvermès nustatyta teigiama silpna koreliacija $(r=0,18 ; r=0,19)$. Tarp paauglių laiko, praleisto prie kompiuterio, ir statinès liemens raumenų ištvermès nustatyti silpni ir vidutinio stiprumo teigiami koreliaciniai ryšiai, tačiau reikšmingas ryšys buvo tik su kairès pusès liemens raumenų statine ištverme $(\mathrm{r}=0,24)$. Vertinant laiką, praleistą naudojantis planšete, ir statinę liemens raumenų ištvermę, gauti neigiami silpni koreliaciniai ryšiai, reikšmingas buvo tik rodiklių ryšys su pilvo raumenų statine ištverme $(r=-0,29)$. Ivvertinus telefono naudojimo trukmès ir laikysenos bei statinès liemens raumenų ištvermès duomenis, nustatyti neigiami silpni ir vidutinio stiprumo, tačiau visi reikšmingi koreliaciniai ryšiai.

Lentelè. Paauglių šiuolaikinių technologijų naudojimo trukmès, laikysenos ir liemens raumenų statinės ištvermès vertinimo rodiklių koreliacija

\begin{tabular}{|c|c|c|c|c|c|}
\hline & $\begin{array}{c}\text { Laikysenos } \\
\text { vertinimas } \\
\text { (balai) }\end{array}$ & $\begin{array}{c}\text { Nugaros } \\
\text { raumenų } \\
\text { statinè } \\
\text { ištvermė }\end{array}$ & $\begin{array}{c}\text { Pilvo } \\
\text { raumenų } \\
\text { statiné } \\
\text { ištvermè }\end{array}$ & $\begin{array}{c}\text { Kairès } \\
\text { pusès lie- } \\
\text { mens } \\
\text { raumenụ } \\
\text { statinè } \\
\text { ištvermè }\end{array}$ & $\begin{array}{l}\text { Dešinės pusès } \\
\text { liemens } \\
\text { raumenụ } \\
\text { statinè } \\
\text { ištvermè }\end{array}$ \\
\hline $\begin{array}{l}\text { Laikysenos } \\
\text { vertinimas } \\
\text { (balai) }\end{array}$ & - & $0,33^{*}$ & 0,18 & 0,19 & $0,41^{*}$ \\
\hline $\begin{array}{l}\text { Praleistas laikas } \\
\text { prie kompiuterio }\end{array}$ & 0,14 & 0,3 & 0,15 & $0,24^{*}$ & 0,16 \\
\hline $\begin{array}{l}\text { Praleistas laikas } \\
\text { prie planšetės }\end{array}$ & $-0,21$ & $-0,19$ & $-0,29 *$ & $-0,04$ & 0,10 \\
\hline $\begin{array}{l}\text { Praleistas laikas } \\
\text { prie telefono }\end{array}$ & $-0,26^{*}$ & $-0,32 *$ & $-0,34^{*}$ & $-0,23 *$ & $-0,33^{*}$ \\
\hline
\end{tabular}

Pastaba. ${ }^{*}-\mathrm{p}<0,05$, koreliacija statistiškai reikšminga.

\section{REZULTATŲ APTARIMAS}

Šiuo tyrimu siekta ịvertinti paauglių laikyseną stovint, jų statinę liemens raumenų ištvermę bei šiuolaikinių technologijų naudojimo trukmę, išsiaiškinti jų ryšius tarpusavyje. Nustatyta, kad paauglių kūno laikysenos sutrikimai yra vis labiau populiarejanti problema pasaulyje. Remiantis tyrimo duomenimis, daugelio 15-17 metų moksleivių (55\%) laikysena netaisyklinga ir beveik visi $(90 \%)$ susiduria su nemaloniais jutimais nugaroje - skausmu (24\%), diskomfortu (27\%) ir nuovargiu 
(49\%). Panašūs rezultatai aptikti S. Murphy'io ir kt. (2004) tyrimo metu - daugelyje valstybių (Kanadoje, Suomijoje ir kt.) nuo 20 iki 51\% mokyklinio amžiaus vaikų jautè nugaros skausmą. Mūsų tyrimo metu taip pat didžioji dalis paaugliu skundèsi nemaloniais jutimais, pasireiškiančiais juosmenineje (43\%) ir viršutinejje (35\%) nugaros dalyje, mažiau nemalonių jutimų pastebèta kakle (9\%) ir visoje nugaroje bendrai (13\%). Tačiau šių jutimų dažnis, daugelio tiriamųų teigimu, yra retas (33\%) ar pasireiškiantis tik kartais (39\%). Taigi galima teigti, kad kuo geresnè paauglių laikysena, tuo galimai ištvermingesni jų raumenys. Puikią laikyseną turinčių moksleivių raumenų ištvermė yra geriausia. Tobulèjančių šiuolaikinių technologijų paplitimas pasaulyje lemia gan dažną šių prietaisų naudojimą tarp jaunų žmonių. Tokie informaciniai ir komunikaciniai įrenginiai kaip kompiuteris, telefonas, planšetinis kompiuteris darosi neatsiejama kasdienio praleidžiamo laiko dalimi. Mūsų tiriamieji šiuolaikinėmis technologijomis naudojosi visi. Tyrimo metu vertintas jų laikas, praleistas naudojant kompiuterį, planšetinį kompiuterị ir telefoną. Paaiškejjo, kad dalis paauglių išvis nesinaudoja kompiuteriu (25\%) ar naudojasi juo labai mažai, iki $1 \mathrm{~h}$ per dieną (35\%), ir tik penktadalis viršijo A. Briggs'o ir kt. (2004) rekomenduojamą normą. Mūsų tyrimo metu nustatyta, kad kompiuterio naudojimo trukmè ir pasireiškiantys nemalonūs jutimai nugaroje nėra susiję. Iš gautų duomenų matyti - kuo daugiau tiriamasis naudojasi kompiuteriu, tuo mažiau arba išvis neturi tokių simptomų kaip skausmas, diskomfortas ar nuovargis. Analizuojant tyrimo duomenis nustatyta, kad nuo praleisto laiko prie kompiuterio trukmès paauglių laikysenos būklè priklauso labai mažai. Nors laikysenos vertinimo balų skaičius atvirkščiai proporcingas prie kompiuterio praleistam laikui, tarp šių vertintų rodiklių yra silpnas teigiamas ryšys $(r=0,14)$. Vertinant statinès ištvermès ir kompiuterio naudojimo trukmės sąsajas nustatyta, kad kuo ilgiau moksleivis sedi prie kompiuterio, tuo ištvermingesnis jo kūnas nustatyti silpni ir vidutinio stiprumo teigiami koreliaciniai ryšiai. Visgi moksleivių, ilgai naudojančių kompiuterį, skaičius yra mažas, todèl duomenys neatspindi visos populiacijos. Kai kurie moksleiviai planšetiniu kompiuteriu nelinkę naudotis kiekvieną dieną (10\%), 5\% naudojasi iki $1 \mathrm{~h}$ per dieną ir 5\% naudojasi $1-2 \mathrm{~h}$ per dieną, o dauguma nesinaudoja planšete apskritai (80\%). Puiki laikysena buvo tuc vaikų, kurie nesinaudojo planšete ar naudojosi ja ne kiekvieną dieną, o tų, kurie naudojosi iki $1 \mathrm{~h}$ ar 1-2 h per dieną, laikysena buvo prastesnè (38 ir 39 balai). Planšetinio kompiuterio naudojimo trukmè neturi didelès ịtakos raumenų statinei ištvermei, tačiau reikšmingas ryšys pastebètas tarp planšetinio kompiuterio naudojimo trukmès ir pilvo raumenų statinès ištvermès $(\mathrm{p}<0,05)$, lyginant su kitomis raumenų grupėmis. Taip pat nustatyta, kad planšetès naudojimas neturi didelès ịtakos pasireiškiantiems simptomams nugaroje, priešingai, kuo daugiau paauglys naudojasi planšete, tuo nemalonių jutimų nugaroje kiekis mažèja. Mobiliuoju te- 
Šiuolaikinių technologijų naudojimo trukmès poveikis paauglių laikysenai ir liemens raumenų statinei ištvermei

lefonu ne skambinimo tikslais naudojosi $95 \%$ moksleivių, kurių 15\% naudojosi iki $1 \mathrm{~h}$ per dieną, $15 \%$ naudojosi $1-2 \mathrm{~h}$ per dieną, $20 \%-2$ ar $3 \mathrm{~h}$ per dieną, o net $45 \%$ paauglių naudojosi 4 ir daugiau valandų per dieną. Toks aukštas naudojimosi telefonu dažnis aprašomas L. Korpinen'o ir kt. (2013) tyrime - nustatyta, kad net $89 \%$ moksleivių mobiliuosius telefonus naudoja dažnai ir ilgai. Geriausia laikysena buvo tų vaikų, kurie nesinaudojo telefonu ne skambinimo tikslais ir tų, kurie naudojosi 2-3 h per dieną, tačiau laikysena kur kas prastesnè tų, kurie praleido 4 ir daugiau valandụ naudodamiesi telefonu. Pastebeta, kad kuo ilgiau paauglys naudojasi telefonu, tuo prastesnè ne tik jo laikysena, bet ir raumenų ištvermè. Ilgiausiai naudojantys telefonus moksleiviai turejjo mažiausiai ištvermingus nugaros, pilvo ir liemens šoninius raumenis. Tarp šių tyrimo rodiklių nustatyti vidutinio stiprumo neigiami, tačiau reikšmingi ryšiai $(\mathrm{p}<0,05)$. Telefono naudojimo trukmé ir pasireiškiantys nemalonūs jutimai nugaroje yra susiję - kuo ilgiau tiriamasis naudoja telefoną, tuo labiau jie pasireiškia. Panašūs duomenys gauti L. Korpinen'o ir kt. (2013) tyrimo metu - nustatyta, kad aukštas telefono naudojimo dažnis ir trukmè lemia kaklo bei viršutinès nugaros dalies skausmo atsiradimą.

Apibendrinant tyrimo duomenis galima teigti, kad hipotezè iš dalies pasitvirtino - šiuolaikinių technologijų trukmès poveikis paauglių laikysenai ir statinei liemens raumenų ištvermei yra susiję silpnais ir vidutinio stiprumo, tačiau reikšmingais koreliaciniais ryšiais. Didžiausią poveikị paauglių fizinei būklei lèmè dažnas ir ilgiausios trukmès naudojimasis mobiliuoju telefonu, tačiau ne kompiuteriu ar planšete.

\section{IŠVADOS}

$10 \%$ tiriamujų nustatyta puiki laikysena, $35 \%$ - gera, $55 \%$ - patenkinama. $\mathrm{Nu}-$ statytas tiesioginis vidutinio stiprumo reikšmingas ryšys tarp paauglių laikysenos ir liemens raumenų statinès ištvermès. Šiuolaikinių technologijų priemonemis kasdien naudojasi 100\% tiriamųų, o vidutinè naudojimosi trukmė yra keturios valandos. Gauti reikšmingi silpni ir vidutinio stiprumo ryšiai tarp šiuolaikinių technologijų naudojimo trukmès ir statinès liemens raumenų ištvermès bei laikysenos.

Finansavimas: nèra.

Interesų atskleidimas: nèra. 


\title{
LITERATŪRA
}

Arcinavičius, S. L., Kesminas, R., Milčarek, E. (2004). Laikysena ir jos vertinimo aspektai. Kineziterapija, 1 (5), 28-35.

Binboğa, E., Korhan, O. (2014). Posture, musculoskeletal activities, and possible musculoskeletal discomfort among children using laptops or tablet computers for educational purposes: A literature review. Journal of Science Education and Technology, 23 (5), 605-616.

Briggs, A., Straker, L., Greig, A. (2004). Upper quadrant postural changes of school children in response to interaction with different information technologies. Ergonomics, 47 (7), 790-819.

Brink, Y., Louw, Q., Grimmer, K. et al. (2013). Development of a cost effective three-dimensional posture analysis tool: Validity and reliability. BMC Musculoskeletal Disorders, 14 (1), 335.

Brink, Y., Louw, Q., Grimmer, K., Jordaan, E. (2014). The spinal posture of computing adolescents in a real-life setting. BMC Musculoskeletal Disorders, 15 (1), 212.

Gold, J. E., Driban, J. B., Thomas, N. et al. (2012). Postures, typing strategies, and gender differences in mobile device usage: An observational study. Applied Ergonomics, 43 (2), 408-412.

Gustafsson, E., Johnson, P. W., Lindegård, A., Hagberg, M. (2011). Technique, muscle activity and kinematic differences in young adults texting on mobile phones. Ergonomics, 54 (5), 477-487.

Hakala, P. T., Rimpelä, A. H., Saarni, L. A., Salminen, J. J. (2006). Frequent computerrelated activities increase the risk of neck-shoulder and low back pain in adolescents. The European Journal of Public Health, 16 (5), 536-541.

Korpinen, L., Pääkkönen, R., Gobba, F. (2013). Self-reported neck symptoms and use of personal computers, laptops and cell phones among Finns aged 18-65. Ergonomics, 56 (7), 1134-1146.

Murphy, S, Buckle, P., Stubbs, D. (2004). Classroom posture and self-reported back and neck pain in schoolchildren. Applied Ergonomics, 35 (2), 113-120.

Paavonen, E. J., Roine, M., Korhonen, P. et al. (2010). Media and children's well-being. Duodecim; laaketieteellinen aikakauskirja, 127 (15), 1563-1570.

Straker, L. M., Campbell, A. C., Jensen, L. M. et al. (2011). Rationale, design and methods for a randomised and controlled trial of the impact of virtual reality games on motor competence, physical activity, and mental health in children with developmental coordination disorder. BMC Public Health, 11 (1), 654.

Young, J. G., Trudeau, M., Odell, D., Marinelli, K., Dennerlein, J. T. (2012). Touch-screen tablet user configurations and case-supported tilt affect head and neck flexion angles. Work, 41 (1), 81-91.

\section{EFFECT OF THE USE OF MODERN TECHNOLOGIES ON POSTURE AND STATIC TRUNK MUSCLE ENDURANCE IN ADOLESCENTS}

\author{
Anelė Gedmantaitė, Vilma Dudonienè \\ Lithuanian Sports University
}

\begin{abstract}
Background. It is observed that rapidly evolving and easily accessible modern technology takes much time from daily lives of children and adolescents (Paavonen et al., 2010). Smartphones, tablets and computers - all portable and stationary, have become an integral part of learning and leisure among young people (Young et al., 2012; Korpinen et al., 2013). There has also been an increase in posture
\end{abstract}


Šiuolaikinių technologijų naudojimo trukmės poveikis paauglių laikysenai ir liemens raumenų statinei ištvermei

disorders in children and adolescents, and frequent complaints of various types of pain in the back, especially in the neck and lower back (Brink et al., 2013; Bimboga, Korhan, 2014).

Aim. Establish links between time of use of modern technologies and adolescents' posture and static muscle endurance.

Methods. The study included 84 subjects (60 girls, 24 boys). The subjects' posture was evaluated using W. W. K. Hoeger (1987) (Arcinavičius et al., 2004) visual posture assessment questionnaire, the technology frequency, duration, sense in the back and physical activity questionnaire and McGill's (2002) methodology for the assessment of static muscle endurance.

Results. Even $90 \%$ of subjects experienced discomfort in the back (13\% of the whole back, $9 \%$ in the neck, $35 \%$ in the upper back, $43 \%$ in the lower back). All subjects used modern technology devices (75\% computer, $10 \%$ tablet, $95 \%$ phone); $10 \%$ of subjects had excellent posture (45-50 points), $35 \%$ - good posture (44-45 points) and 55\% of subjects had satisfactory posture (39-30). The average posture point of those who did not use the computer was 40.2 points, and of those who spent 4 hours or more -43 , of those who did not use the tablet -40 , of those who used the tablet for 1-2 hours -39 . Subjects who did not use the phone more than when calling -42 points, those who used 4 hours or more -38.7 points. When assessing the posture of school children and the static endurance of the torso muscles, a positive, moderate, significant correlation between posture and dorsal and right-side static trunk muscles endurance $(r=0.33 ; r=0.41)$ was found, time spent at the computer and static trunk muscle endurance - weak and moderate positive correlations, and a significant relationship with left-sided static trunk muscles endurance $(r=0.24)$. When assessing the time spent using the tablet and static endurance of the torso muscles, we found negative, weak correlation relationships, and significant relationship with abdominal muscle static endurance $(\mathrm{r}=-0.29)$. After assessing the time used with phone, posture and endurance, all significant, negative and weak/moderate correlations were identified.

Conclusions. Even $10 \%$ of subjects had excellent posture, $35 \%$ - good, $55 \%-$ satisfactory. There was a direct, moderate significant relationship between adolescent posture and torso muscle static endurance. Modern technology was used by $100 \%$ of subjects daily, and the average time was four hours. There awere significant, weak and moderate relationships between the time of using modern technologies, the endurance and posture of the static muscles of the trunk.

Keywords: modern technology, adolescent posture, static muscles.

Gautas 20201109

Priimtas 20201201 